TABle II-Prospective Study: Histories of 10 Patients who experienced Perceptual Disturbances after the Administration of Analgesics

\begin{tabular}{|c|c|c|c|c|c|c|}
\hline Age & Sex & Diagnosis & Pentazocine Dosage & $\begin{array}{c}\text { Morphine Tartrate/ } \\
\text { Cyclizine Tartrate Dosage }\end{array}$ & Concurrent Drug Therapy & $\begin{array}{l}\text { Patients' Descriptions of } \\
\text { Perceptual Disturbances }\end{array}$ \\
\hline 22 & F. & $\begin{array}{l}\text { Urinary tract } \\
\text { infection }\end{array}$ & $30 \mathrm{mg}$ i.m. $\times 1$ & - & Nitrazepam, nitrofurantoin & $\begin{array}{l}\text { Saw goldfish and aeroplanes rising out of } \\
\text { cracks in the floor. }\end{array}$ \\
\hline 25 & F. & Headache & $30 \mathrm{mg}$ i.m. $\times 1$ & - & - & $\begin{array}{l}\text { Saw tigers advancing and retreating from a } \\
\text { semi-circle at the end of her bed. Saw a } \\
\text { court of law with no one in the dock and } \\
\text { subsequently various people she knew } \\
\text { appeared vividly. }\end{array}$ \\
\hline 48 & F. & Acute cholecystitis & $50 \mathrm{mg}$ i.m. & - & Crystamycin prochlorperazine & $\begin{array}{l}\text { Heard strange noises accompanied by } \\
\text { vertigo. }\end{array}$ \\
\hline 47 & F. & $\begin{array}{l}\text { Carcinoma of the } \\
\text { breast }\end{array}$ & $50 \mathrm{mg}$ orally & - & Nitrazepam & Felt a floating, rocking sensation. \\
\hline 59 & M. & Amputation & $50 \mathrm{mg}$ orally & - & $\begin{array}{l}\text { Ampicillin, cloxacillin, } \\
\text { frusemide, potassium chloride }\end{array}$ & Felt the roof was falling in on top of him. \\
\hline 53 & M. & $\begin{array}{l}\text { Carcinoma of the } \\
\text { stomach }\end{array}$ & $90 \mathrm{mg}$ i.m. & 一 & - & $\begin{array}{l}\text { Saw people and pink shapes running } \\
\text { up and down the ward. }\end{array}$ \\
\hline 52 & F. & Prolapsed cystocele & $60 \mathrm{mg}$ i.m. & - & Ampicillin, diazepam & $\begin{array}{l}\text { Saw her son who was known by her to be } \\
\text { several hundreds of miles away coming to } \\
\text { visit her. }\end{array}$ \\
\hline 74 & F. & Gangrenous toe & $50 \mathrm{mg}$ orally & - & Cephalexin & $\begin{array}{l}\text { Described a fearful period when she was } \\
\text { able to see strange things like red devils. }\end{array}$ \\
\hline 71 & F. & $\begin{array}{l}\text { Ischaemic heart } \\
\text { disease }\end{array}$ & $30 \mathrm{mg}$ i.m. & - & - & $\begin{array}{l}\text { Saw and talked to people round the end } \\
\text { of her bed who were not there. }\end{array}$ \\
\hline 63 & M. & Perforated peptic ulcer & - & $7.5 \mathrm{mg}$ i.m. & Tetracycline & $\begin{array}{l}\text { Saw people at the end of his bed who were } \\
\text { not there. }\end{array}$ \\
\hline
\end{tabular}

ated to the drug, and apparently it was not associated with dependence in any appreciable number of patients.

This work was assisted by research grants from the Department of Health and Social Security, the Scottish Home and Health Department and the World Health Organization. We would like to thank Professor J. Crooks and Professor R. D. Weir for advice, and the medical staff of the Aberdeen and Dundee Hospitals and the general practitioners in the North-east of Scotland for their co-operation.

\section{References}

Coull, D. C., Crooks, J., Davidson, J. F., Gallon, S. C., and Weir, R. D. (1970). European fournal of Clinical Pharmacology, 3, 46.

Crooks, J.; Clark, C. G., Caie, H. B., and Mawson, W. B. (1965). Lancet, $1,373$.

De Nosaquo, N. (1969). Journal of American Medical Association, 210, 502.

Edison, G. R. (1969). New England fournal of Medicine, 281, 447.

Hart, R. H. (1969). Lancet, 2, 690.

Mungavin, J. M. (1969). Lancet, $2,56$.

Sandoval, R. G., and Wang, R. I. H. (1969). New England fournal of Medicine, 280,1391 .

Scolar, J. C., Idanpaan-Heikkila, P., and Keats, A. S. (1969). Lancet, 1,32

\title{
Respiratory Intensive Care: A Io-Year Survey
}

\author{
R. K. B. YOUNG, \\ D. CAMPBELL, J. M. REID, \\ A. B. M. TELFER
}

British Medical fournal, 1974, 1, 307-310

\section{Introduction}

\section{Summary}

The work of the respiratory intensive care unit at the Glasgow Royal Infirmary covering a period of 10 years and involving more than 2,000 patients has been analysed. The rate of admission of patients with acute respiratory or metabolic disturbances remained surprisingly constant over the years, allowing for the increase in available beds after 1965. A disturbing feature was the notable increase in the incidence of severe self-poisonings. The continued importance of infection as a life-threatening complication is also emphasized. The reduction in mortality observed in some of the most gravely ill patients appears to justify this approach to patient care.

Some years ago the report of the B.M.A.'s Working Party on Intensive Care was published. ${ }^{1}$ The survey was based on a study of 15 representative intensive care units throughout the United Kingdom in both teaching and district hospitals. Commenting on the information derived from the survey the authors underlined the need at that time for more details on the nature of the work done in the various units, the pattern of admission, staffing, and methods of management. As a result of this we produced a report based on four years' experience of respiratory intensive care in a large teaching hospital in an industrial environment. 2 Some six years later it seemed worth while to re-examine the pattern of admissions to the eight-bed respiratory intensive care unit at the Glasgow Royal Infirmary to see if there had been any significant changes in the pattern of admissions, the incidence of certain conditions, and morbidity. The results are reported here.

\section{Results}

The Glasgow Royal Infirmary is a major teaching hospital with a large emergency commitment for both medical and surgical 
patients. In the period under review (1962-72) there was a $40 \%$ increase in admissions-from 21,509 in 1962 to 29,932 in 1972. This occurred despite an approximate $10 \%$ reduction in the population served. During the same period 2,216 patients were treated in the respiratory intensive care unit-that is, somewhat less than $0.01 \%$ of the total hospital admissions. The yearly admission rates to the unit during the period are shown in fig. 1. From 1966 onwards the present eight-bed unit succeeded the four-bed pilot unit.

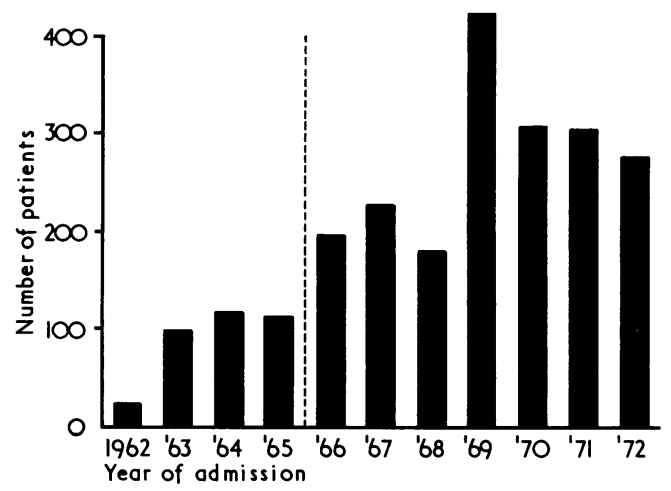

FIG. 1-Yearly admissions to intensive care unit over 10-year period. Broken line indicates change from four-bed unit to present eight-bed unit. Trend is towards steady increase apart from 1969. This apparent discrepancy is wholly accounted for by chance increase in number of postoperative and wholly accounted for by chan

From the outset patients have been arbitrarily classified according to the major precipitating factor leading to the respiratory disturbance-for example, post-traumatic, postoperative, self-poisoning and accidental poisoning, and a miscellaneous group comprising paralytic disorders and chronic airways disease. The frequency with which these conditions were treated in the unit each year is shown in fig. 2. About one-third of the admissions in any year were poisonings and miscellaneous conditions, one-third were post-traumatic cases, and the remainder were patients who developed respiratory insufficiency after surgery. Significantly, the only noticeable trend throughout was an increase in the number of poisoning cases.

Over the 10-year period there was a fairly constant pattern of age distribution in each category of patients treated (fig. 3). The younger patients were found in the traumatic and poisoning groups, while the postoperative patients were noticeably older. Most patients required intensive therapy for up to seven days but

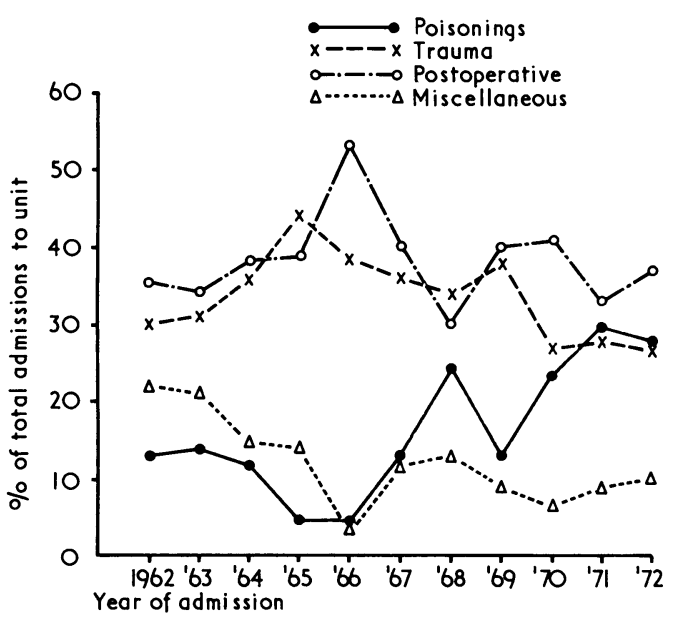

FIG. 2-Number of admissions yearly in each group as percentage of total admissions in that year. Increase in self-poisonings is clearly seen. many required continuing treatment beyond this time (fig. 4). As might be expected the duration of stay varied greatly with the group of patients treated. Most self-poisonings, for instance, were relatively short-stay cases.

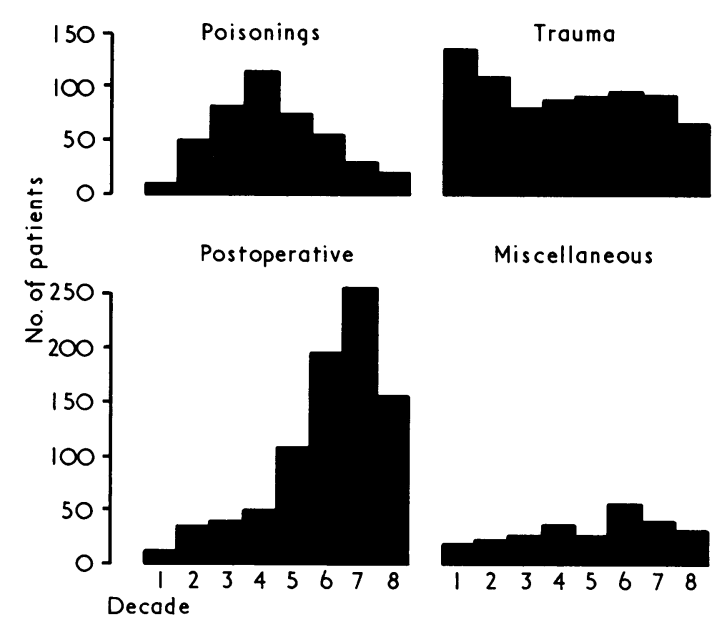

FIG. 3-Age distribution of patients in each group.

The overall hospital mortality from 1962 to 1972 was $4.1 \%$, the figure for surgical patients alone being $2 \cdot 1 \%$. In the same period the overall mortality in the intensive care unit was $23.6 \%$, that for female patients being $22.9 \%$ and for males $24 \cdot 1 \%$. The percentage mortality by age in each group of patients treated in the unit is shown in fig. 5. The overall mortality in each group during the 10-year period is also shown. As might be expected mortality increased steeply with age in patients suffering from respiratory insufficiency after trauma. There was a similar correlation with age for those patients with advanced lung disease and paralytic disorders in the miscellaneous group. It will be observed that from the second decade the mortality in patients developing respiratory insufficiency after surgery was fairly constant. The overall mortality of $18.4 \%$ in this group of patients was also the second lowest, only the poisonings having a better survival rate.

The work load in the unit and the intensity of the therapy applied is probably best shown by reference to the nature of the respiratory support measures carried out. As a large proportion of more gravely ill patients have a combined respiratory and renal problem it is also of importance to note the incidence of special renal therapy required-for example, haemodialysis. The proportion of patients who required active respiratory support such as the introduction of an endotracheal tube or mechanical support to respiration is shown in table I. Over $40 \%$ of the patients required an endotracheal tube, while the tracheostomy rate was

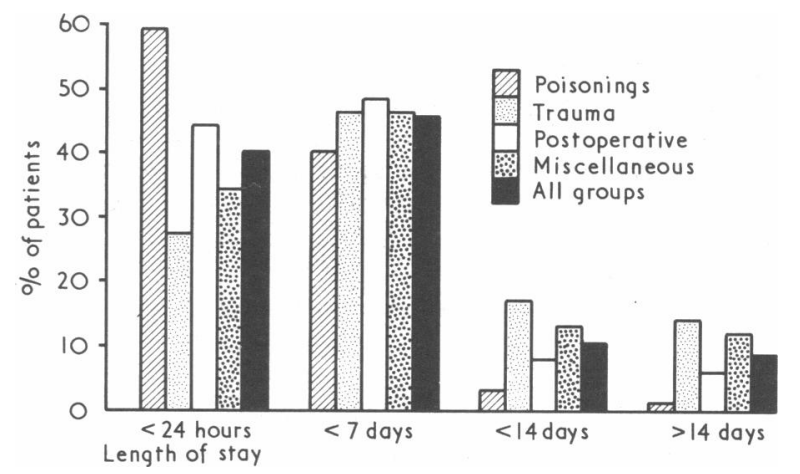

FIG. 4-Length of stay of patients in intensive care unit. Each column represents percentage of patients treated for given period of time, averaged over entire 10 -year period. 


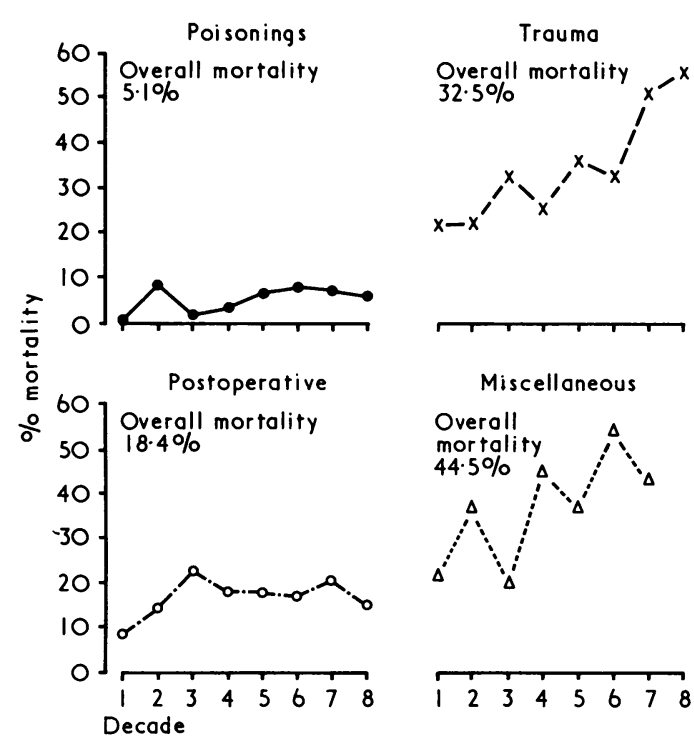

FIG. 5-Mortality per decade for each group. Overall mortality for each category of patient is also shown.

around $14 \%$. One-quarter of the patients required intermittent positive-pressure ventilation (I.P.P.V.) for a shorter or longer period. The special measures required to support inadequate renal function are listed similarly in table II. The four techniques generally employed were forced alkaline diuresis in the cases of poisoning, diuretic therapy in all groups, and haemodialysis or peritoneal dialysis, again in all patients. The first three techniques were carried out in the respiratory intensive care unit, while haemodialysis was performed in the renal unit under the supervision of the renal physicians caring for the individual patients.

It has been generally recognized that a serious complication and significant contribution to morbidity and mortality in these severely ill patients is secondary infection, especially with Gramnegative bacteria, and, more recently, the bacterioides group of organisms. Bacteriological control of intensive care areas is therefore mandatory, especially where the admission of already infected patients is unavoidable. In the present series of patients about $10 \%$ were proved to have significant respiratory infection both clinically and bacteriologically at the time of admission and a further $10 \%$ became infected at some point during treatment (table III).

rABLE I-Percentage of Patients in each Group needing Respiratory Support

\begin{tabular}{|c|c|c|c|c|c|}
\hline & Trauma & Postoperative & Poisonings & Miscellaneous & Overall \\
\hline $\begin{array}{l}\text { Endotracheal tube } \\
\text { Tracheostomy } \quad . . \\
\text { I.P.P.V. .. }\end{array}$ & $\begin{array}{l}36 \cdot 3 \\
19 \cdot 3 \\
21 \cdot 3\end{array}$ & $\begin{array}{l}34 \cdot 3 \\
12 \cdot 9 \\
27 \cdot 1\end{array}$ & $\begin{array}{r}65 \cdot 5 \\
2 \cdot 7 \\
21 \cdot 0\end{array}$ & $\begin{array}{l}58 \cdot 2 \\
19 \cdot 8 \\
42 \cdot 7\end{array}$ & $\begin{array}{l}43.5 \\
13.7 \\
25.5\end{array}$ \\
\hline
\end{tabular}

TABLE II-Number of Patients in each Group needing Renal Therapy. Percentages are given in Parentheses

\begin{tabular}{|c|c|c|c|c|c|}
\hline & Trauma & Postoperative & Poisonings & Miscellaneous & Overall \\
\hline $\begin{array}{c}\text { Forced alkaline } \\
\text { diuresis .. }\end{array}$ & $\mathbf{0}$ & 0 & $138(33 \cdot 3)$ & $0(0)$ & $\begin{array}{c}138 \\
(6 \cdot 2)\end{array}$ \\
\hline $\begin{array}{c}\text { Mannitol/frusemide } \\
\text { diuresis .. }\end{array}$ & $48(1 \cdot 3)$ & $118(13.5)$ & $12(2 \cdot 9)$ & $18(7 \cdot 9)$ & $\begin{array}{c}196 \\
(8 \cdot 8)\end{array}$ \\
\hline Peritoneal dialysis & $1(0 \cdot 1)$ & $1(0 \cdot 1)$ & $4(1 \cdot 0)$ & $5(2 \cdot 1)$ & 11 \\
\hline Haemodialysis .. & $12(0 \cdot 3)$ & $9(1 \cdot 0)$ & $6(1 \cdot 5)$ & $4(1 \cdot 6)$ & $\begin{array}{c}(0.5) \\
31 \\
(1 \cdot 4)\end{array}$ \\
\hline
\end{tabular}

TABLE III-Percentage of Patients in each Group who acquired Infection before and after Admission to Intensive Care Unit

\begin{tabular}{l|c|c|c|c|c}
\hline & Trauma & Postoperative & Poisonings & Miscellaneous & Overall \\
\hline $\begin{array}{l}\text { Before admission } \\
\text { After admission .. }\end{array}$ & $\begin{aligned} 3.8 \\
16.5\end{aligned}$ & $\begin{array}{c}12.3 \\
7.8\end{array}$ & $\begin{array}{l}0.9 \\
1.2\end{array}$ & $\begin{array}{c}29.4 \\
10.1\end{array}$ \\
\hline
\end{tabular}

\section{Discussion}

Most teaching hospitals and many district hospitals have now instituted a system of intensive therapy units. Some may accept all types of patients, from cases of myocardial infarction to those in acute respiratory failure, but normally there is a separation of patients with these conditions. The unit at the Glasgow Royal Infirmary admits cases of respiratory disturbance whether medical or surgical in origin and also manages a number of acute metabolic problems. While an increasing number of reports have appeared in the world literature dealing with specific therapeutic problems, describing actual techniques and methods of treatment, there is still a paucity of information of a more general nature. It is desirable that this type of information also be recorded and disseminated as a guide to those concerned in the planning of similar facilities, particularly in new hospitals, and also to those interested in the epidemiology of the various conditions necessitating intensive respiratory supportive therapy. The present report is intended to provide some information which may be helpful in this area.

It is felt to be essential that all units such as the present one should develop a reliable and simple method of data storage and retrieval. With staff shortages and the increasing demands on skilled secretarial help the chosen method of recording should be capable of operation by a clinician with minimal time to spare and little secretarial help. The feature index system employed in this department reliably meets these criteria. The system enables continuous monitoring of various aspects of organization and patient care which can result in early detection and correction of deficiencies in management and even alteration in methods of treatment selected. Since intensive therapy implies intensive observation and accurate measurement it seems important to begin by measuring the overall work of such units in this way.

The results presented above to some extent speak for themselves. Some commentary, however, is warranted and also some tentative interpretation of the figures presented. It is important to determine the context in which the discussion of intensive care is made. The population shifts in the east side of the City of Glasgow, for example, were considerable in the period under review and might well have been expected to have a profound effect on hospital admissions and hence the work of the respiratory intensive care unit. In addition, the overall reduction in population of some $10 \%$ would be expected to influence matters but, in fact, there was a $40 \%$ increase in admissions over the 10 years to the hospital at large and a fairly constant admission rate to the intensive care unit of around $0.01 \%$ of the total hospital admissions. Better bed utilization probably accounted for the increase in patient turnover. The proportion of patients admitted in each classification also remained remarkably constant, with about equal numbers of surgical, traumatic, and medical conditions.

One of the few marked trends was the disturbing increase in the incidence of poisonings, and these patients now comprise the largest group of medical cases treated, more than compensating for the reduction in numbers of patients suffering from acute exacerbation of chronic airways disease. In our experience selfpoisoning as a cause of morbidity is beginning to rival road accidents, with 440 patients admitted in the 10 years $(5.1 \%$ mortality) compared with 413 road-accident cases ( $32.4 \%$ mortality). This appalling fact was discussed by Matthew. ${ }^{3}$

To justify the term intensive care unit some measure must be applied to assess quantitatively and qualitatively the actual 
nature of the work done. A useful index is felt to be the degree of complexity of special respiratory support and other therapy required by the patients. In this series active measures to secure and maintain a patent airway were required in over $40 \%$ of patients, while mechanical support to ventilation itself was needed in $25 \%$. The need for the presence of fully trained anaesthetists in this situation is self-evident.

As acute reversible intrinsic renal failure (acute tubular necrosis) is a not uncommon complication in these patients the amount of special therapy required in this respect also gives some indication of the nature of the work done. Over $15 \%$ of the patients required one or other of the recognized forms of special renal therapy. While the number of patients undergoing haemodialysis is never great they tend to be long-term patients, and thus the risk of serum hepatitis is always present in a respiratory intensive care unit. This risk is aggravated by the high incidence of arterial and venous blood sampling required for proper patient management. Additional hazards are presented by the frequency of multiple blood transfusions and the occasional unsuspected carrier. This situation emphasizes the need for more stringent precautions to protect staff and for such units to be designated high-risk areas when considering the problem of possible compensation for medical and nursing staff.4

A major hazard remains that of cross-infection, since these gravely ill patients are especially vulnerable to this complication. The problem is made more difficult when it is seen that some $10 \%$ of admitted patients already have a significant respiratory infection as judged clinically and bacteriologically. Most infected patients are admitted from other areas of the hospital, especially the postoperative cases and those with medical conditions. Every available measure must be rigorously applied to limit this risk, including adequate ventilation of the ward, scrupulous sterilization of apparatus, employment of "one-use" equipment, and constant bacteriological surveillance of all patients. This unit employs positive-pressure ventilation and two isolation cubicles in addition to wide spacing of beds, and all known methods of control are constantly in operation and under critical review. Prophylactic antibiotic therapy with its wellknown risk is avoided. ${ }^{5}$ Despite all precautions $10 \%$ of patients acquire a respiratory infection of minor or major significance after admission, particularly the long-stay patients with a prolonged exposure time. Eternal vigilance is obviously the price of safety in this respect.

Finally, it would be naive and misleading to regard every living patient transferred from the intensive care unit as having fully recovered. Only adequate follow-up will show the quality of recovery and whether a happy and useful person has been returned to the community. As an indication, however, of the value and efficacy of the intensive approach to treatment of these critically ill patients it may suffice to observe that during the 10-year period under review the mortality rate in severe chest injuries alone fell from $52 \%$ to $25 \cdot 8 \%$.

We wish to express our deep appreciation of the continued support in the management of these patients afforded by the nursing and ancillary staff of the intensive care unit. We are also grateful for the unfailing co-operation of our medical, laboratory, and technical colleagues. Finally, our thanks are due to Mrs. Helen Maxwell, secretary to the intensive care unit, and Miss Ann Taggart, of the department of medical records of the Royal Infirmary.

\section{References}

1 Working Party of British Medical Association's Planning Unit, Intensive Care (Report No. 1). London, British Medical Association, 1967.

2 Campbell, D., Reid, J. M., Telfer, A. B. M., and Fitch, W., British Medical fournal, 1967, 4, 255.

Department of Health and Social Security, Hepatitis and the Treatment of Chronic Renal Failure. London, H.M.S.O., 1972.
enartiont

5 Price, D. J. E., and Sleigh, J. D., Lancet, 1970, 2, 1213.

- Sullam, I. A., Mackey, W. A., and Bain, W. H., British fournal of Surgery, $1970,57,722$.

\title{
Subungual Malignant Melanoma: Difficulty in Diagnosis
}

\author{
BARBARA LEPPARD, ,K. V. SANDERSON， F. BEHAN
}

British Medical fournal, 1974, 1, 310-312

\section{Summary}

Subungual malignant melanoma developed on both great toes of a 61-year-old woman. The lesions had been diagnosed elsewhere as ingrowing toenails and had been treated as such for two years. The difficulty in clinical diagnosis is illustrated by the description of three other patients with subungual malignant melanoma. The tumour should be considered as a possible cause of any persistent abnormality of the nail bed or the nail itself, especially if it is pigmented.

\footnotetext{
Departments of Dermatology and Plastic Surgery, St. George's Hospital, London S.W.1

BARBARA LEPPARD, M.B., M.R.c.P., Senior Registrar (Present address: St. John's Hospital for Diseases of the Skin, London W.C.2) K. V. SANDERSON, M.B., F.R.C.P., Physician

F. BEHAN, F.R.A.C.S., F.R.C.s. First Assistant Plastic Unit
}

\section{Introduction}

Since Hutchinson ${ }^{2}$ first described it melanotic whitlow has remained a problem in diagnosis. He pointed out that though it looks like a chronic whitlow careful observation will show the pigmented band bordering the inflamed area. He remarked that the diagnosis is always missed in the early stage; subsequent descriptions and the following case reports show that this is still true. It is seen early by the patient but diagnosed late by the doctor: ${ }^{3}$

Case 1.-A 61-year-old housewife was first seen at another hospital in July 1969 with a painful right ingrowing toenail. The nail was apparently very deformed and necrotic and was removed under general anaesthetic. The wound did not heal and no nail regrew. Eleven months later the right great toenail bed was red and macerated and the left great toenail was "ingrowing." The nail bed of both great toes was excised but not histologically examined. Neither wound healed though the patient was in hospital for several weeks. She was referred to us in September 1971 because the wounds had still not healed, and she said that two to three weeks previously a pigmented band had developed in the red friable area on the dorsum of the right toe. 